\title{
An experimental study of the replacement of calcite by siderite
}

\author{
MANUEL KNORSCH ${ }^{1,2}$, FANG XIA ${ }^{1, *}$, ARTUR P. \\ Deditius $^{1}$, MARK A. PeArCE ${ }^{2}$ \\ ${ }^{1}$ Discipline of Chemistry and Physics, CSHEE, Murdoch \\ University, Perth, WA 6150, Australia \\ (*correspondence: f.xia@murdoch.edu.au) \\ ${ }^{2}$ CSIRO Mineral Resources, Australian Resources Research \\ Centre, Perth, WA 6151, Australia
}

Carbonate minerals are prone to fluid-driven mineral replacement reactions, from low-temperature dolomitization of calcite to high-temperature metamorphic reactions. These replacement reactions can change the chemical and isotopic compositions of minerals and generate porosity and permeability in rocks. We carried out an experimental study of the replacement of calcite by siderite in Fe-rich hydrothermal saline fluids and investigated the effects of solution pH (1.78-11.02), time (2-1680 h), temperature (60$200{ }^{\circ} \mathrm{C}$ ), and the crystallinity of parent calcite on the replacement rate, and on the composition and texture of the product phases.

The replacement reactions followed the interface coupled dissolution reprecipitation mechanism, and the reaction rate

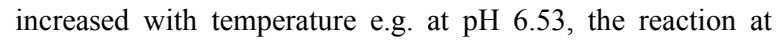
$125^{\circ} \mathrm{C}$ is $>30$ times faster than at $60{ }^{\circ} \mathrm{C}$. Variable amounts of $\mathrm{Ca}$ substitute for $\mathrm{Fe}$ in the siderite product, forming a partial siderite-calcite solid solution (scss). The $\mathrm{Ca} / \mathrm{Fe}$ ratio in scss increased with temperature, from $0.017 \pm 0.005$ at $60^{\circ} \mathrm{C}$, to $0.042 \pm 0.021$ at $125^{\circ} \mathrm{C}$ and $0.063 \pm 0.044$ at $200{ }^{\circ} \mathrm{C}$, and decreased with time, from $0.141 \pm 0.071$ after 2 hours to $0.031 \pm 0.007$ after 864 hours of reaction at $200^{\circ} \mathrm{C}$ and $\mathrm{pH}$ 6.53. This suggests kinetic control in the early stage and reequilibration of the product phases in the later stage of the reaction. The replacement is pseudomorphic, indicating calcite dissolution is the rate-limiting step. At $200{ }^{\circ} \mathrm{C}$, akaganeite $\left[\mathrm{Fe}^{3+} \mathrm{O}(\mathrm{OH}, \mathrm{Cl})\right]$ precipitated as additional product phase and formed $5-15 \mu \mathrm{m}$ thick layers alternating with scss. Interbedded layers of akaganeite may form due to the cyclic local supersaturation of the fluid during the replacement reactions. Under all experimental conditions, porosity was generated in scss. The spatial distribution and the size of pores depend on $\mathrm{pH}$; a dense shell hollow-core structure was observed in near-neutral solutions ( $\mathrm{pH} 3.75-7.19)$.

This study shows that mineral replacement reactions in carbonates are sensitive to reaction conditions, particularly temperature, and highlights the complex interplay between kinetics and thermodynamics in determining the composition, texture, and porosity of the product phases. 